\title{
The Influence of Convenience, Easy Usage, and Promotion Towards People's Interest in Using Ovo Application (Non Cash) In Denpasar City
}

\author{
Ni Wayan Ari Sudiartini ${ }^{1}$, Anak Agung Elik Astari ${ }^{2}$, Ni Luh Kardini ${ }^{3}$ \\ \{wayan.ari1987@gmail.com¹, kardini.mahayoga@gmail.com² ${ }^{2}$ elik.adoenku@gmail.com ${ }^{3}$ \} \\ Faculty of Economics, Mahendradatta University, Bali ${ }^{1,2,3}$
}

\begin{abstract}
Non-cash transactions (cashless) are implemented in various sectors. A study revealed that $80 \%$ of Indonesians prefer to use an electronic payment card compared to cash. OVO is a smart application that allows its users to do online payment and transaction services (OVO Cash). This study aims to find out the influence of convenience, easy usage, and promotions towards people's interests in using OVO application (Non Cash) in Denpasar. The samples used in this study were saturation with the number of respondents 100 people. Measurements in the questionnaire used the scale of Likert and the analysis was done using double linear regression statistic method followed by conducting test $\mathrm{T}$ and test $\mathrm{F}$ at a level of significant $10 \%$ also to find out the magnitude of total and variable influence that give dominant effect. Based on the analysis done using SPSS, it is noted that, partially, convenience, easy usage, and promotions affect people's interest in using OVO application significantly. Simultaneously, variables of comfort, easy usage, and promotion have a significant effect on the use interest of OVO applications in Denpasar. The magnitude of influence is based on the determination coefficient value $(\mathrm{r} 2)=0.979$ which means that 97.9\% of the variety of riding interest in the use of OVO applications in Denpasar is influenced by convenience, easy usage, and promotion while the remained $2.1 \%$ is influenced by other variables that are not mentioned in this research model.
\end{abstract}

Keywords: Non cash, OVO application, Transaction convenience

\section{Introduction}

Non-cash transactions (cashless) are implemented in various sectors. One interesting fact of the non-cash transactions is the market trend that is still dominated by the need for discounts as a part of the youth's shopping habit. According to the Nielsen survey in 2016, rewards in the form of rebate or cashback is still in the top line of market needs for the company to win the customer's heart. In fact, the trend is still ongoing and will continue to grow among the people. Recognizing this phenomenon, OVO provides services with a variety of facilities, safety, and convenience for people in transacting and shopping.

OVO is a smart application that provides online payment and transaction services (OVO Cash). There is also a chance for consumer to collect points every time they make a payment transaction through OVO. In general, OVO Cash can be used for a wide range of payments that have collaborated with OVO. OVO Points is a loyalty rewards for the consumers that have done transactions using OVO Cash at OVO partner merchants. OVO Points can be redeemed for various attractive offers or exchanged for transactions at OVO partner merchants. 
OVO offers easy transactions without requiring customers to carry too much cash. One of them is to simply show the OVO application in which there is cash or point balance. In the OVO app, the funds are divided into two, OVO Cash and OVO Points. OVO Cash is the amount of money that the costumers have in their digital wallet. OVO Cash is the balance that is used for payments at all merchants. While OVO Points are points that can be accumulated through a cashback or loyalty program of OVO.

OVO has two types of memberships, namely OVO Club and OVO Premier. One of the differences between the two is the OVO Premier members can store OVO Cash up to 10 million Rupiahs. To register or upgrade from the OVO Club account to OVO Premier, users only need to send a photo of the KTP through the OVO app or register directly through the OVO kiosks that are available in many places.

The payment methods in Southeast Asian countries including Indonesia have undergone tremendous growth over the last 10 years. New technological innovations, wider Internet access, and growing number of people with mobile devices are the things that drive rapid development in the making of payment transactions. Consumers nowadays do not like to linger in line at the cashier they prefer to shop from home using mobile app and get the products delivered directly to the house. The consumers prefer taxis that come to pick them up, and prefer to book hotel room online through their smartphones. Businesses can accept electronic payment tools and facilitate consumers in digital payments and reduce cash usage.

\section{Method}

This study aims to find out the factors that influence the purchasing power of people in traditional markets in Denpasar. This research applied quantitative research method with a descriptive data analysis approach. According to Arikunto (2006), quantitative research is a research that uses a lot of numbers, ranging from data collection, interpretation of the data, and the appearance of the results [1]. Meanwhile, according to Masyhuri and Zainuddin (2008), quantitative research is a research that does not focus on the depth of the data, quantitative research is not very focused on the depth of data, what important is to record as much data from the vast population [2].

This research seeks to test hypotheses that utilize the causal relationship of several variables, namely the influencing factors analysis affecting the purchasing power of people in traditional markets in Denpasar, whether the income level, price, and quality of this service affects the purchasing power of people in traditional markets in Denpasar.

The population in this study is OVO users in Denpasar City. The sample is part of the number and characteristics owned by the population. This study used the accuracy rate $(\alpha)$ by $5 \%$ and confidence level of $95 \%$ so that the value obtained $\mathrm{Z}=1.96$. Acceptable error rate of $10 \%(0.1)$. Then, the probability of the questionnaire is true $\mathrm{q}$ (received) or false $\mathrm{p}$ (rejected) respectively $50 \%(0.5)$. Therefore, the sample that was used to represent the population is as much as 100 respondents. The sampling technique used in this study is purposive sampling. Purposive sampling is the determination of the sample with certain considerations, for example the person is considered to have the knowledge about what we hope, so that it will facilitate the researcher to explore the object or social situation studied. The framework of this research can be seen in Fig 1. 


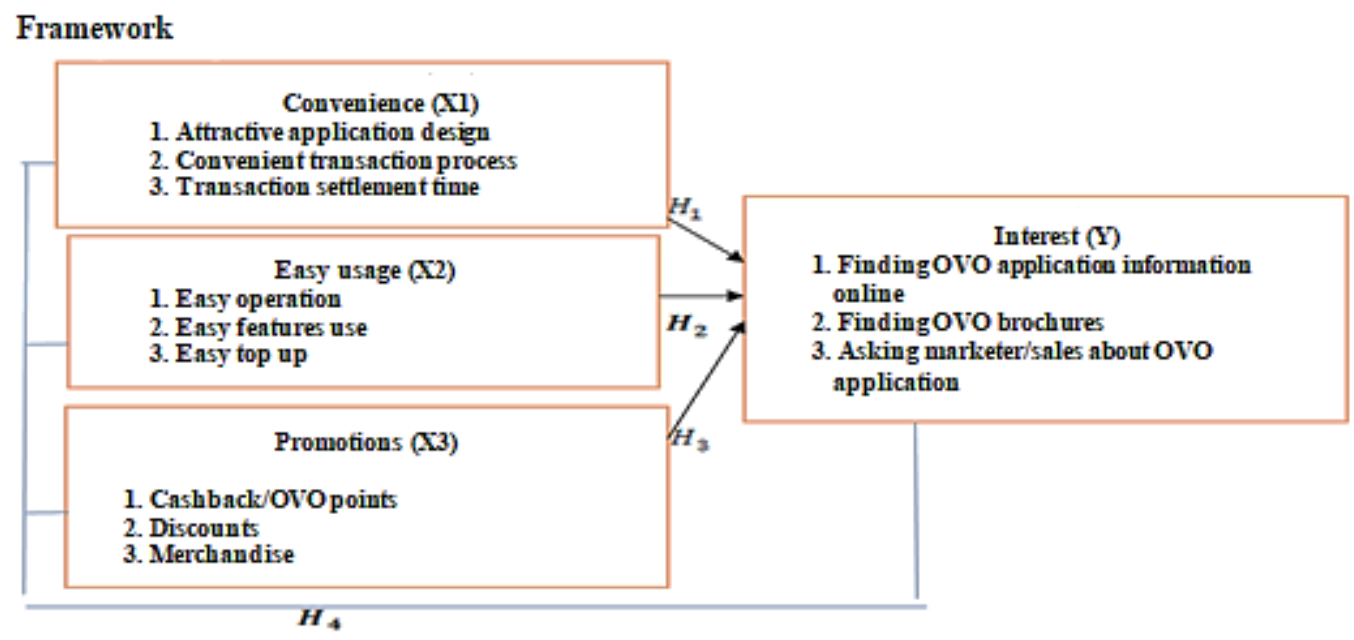

Fig.1. Framework

\section{Results and Discussions}

OVO is a digital wallet service (smart financial apps) that offers a variety of transactions at many OVO partners. The company is a part of Lippo groups that is LippoXOvo which is first launched in March 2017 and is under the auspices of PT Visionet International. In the beginning, OVO established cooperation with other LIPPO companies such as Hypermart and Siloam hospital. Nevertheless, OVO was designed to be open platform. In May 2018, Lippo Group and Tokyo Century have formed a series of partnerships in Indonesia including investments in OVO, where Tokyo Century invested about US \$120 million. In July 2018, OVO announced strategic partnerships with several important companies in Indonesia. The partners are Bank Mandiri, Alfamart, Grab, and Moka. This new partnership, along with the partnership that has been established with Lippo network, makes OVO the payment platform with the widest acceptance in Indonesia. To expand its user base, OVO also announced a cooperation with the Tokopedia online shopping platform in November. Tokopedia then officially partnered with OVO as a substitute for Tokocash digital payment. OVO added 80 million of Tokopedia's monthly active users to 60 million OVO user base.

\subsection{The influence of convenience towards people's interest in using OVO applications (Non Cash) in Denpasar City}

Based on the calculations done, obtained $t$ value thitung $=8.938$ compared to ttabel $=1.6$ and the significance rate of 0.000 , less than 0.05 . This means that convenience variables partially give positive and significant influences towards people's interest in using OVO application. This is in line with the research conducted by Valentina Ayudya Jayaningrum (2019) that factor of convenience (trust) give positive effect which shows that OVO has been accepted by the people [3]. There are a lot of outlets, roadside stalls, even markets that already use OVO as a means of payment. On the other hand, many users use OVO because of the cashback offered by OVO is quite a lot. The use of OVO is considered effective and efficient because it does not require cash in the transaction process. 


\subsection{The influence of easy usage towards people's interest in using OVO application (Non Cash) in Denpasar City}

Based on the calculations done, obtained $t$ value thitung $=14,319$ compared to ttabel $=1.6$ and the significance rate of 0.000 , less than 0.05 . This means that easy usage variables partially give positive and significant influences towards people's interest in using OVO application. This is in line with the results of research conducted by Ahmad Ilyin and Widiartanto (2020) that stated that the perception of ease-of-use effect is positive and significant against OVO usage decisions [4]. It shows that the easier the use of e-money given by the company the better or higher the decision of use by consumers. Therefore, OVO should educate the consumers regarding the advantages of OVO compared to other emoney to be able to convince people to use OVO.

\subsection{The influence of promotion towards people's interest in using OVO applications (Non Cash) in Denpasar City}

Based on the calculations done, obtained $t$ value thitung $=7,128$ compared to ttabel $=1.6$ and the significance rate of 0.000 , less than 0.05 . This means that promotions variables partially give positive and significant influences towards people's interest in using OVO application. This is in line with the research conducted by Ardiray Syafutra (2019) states that the promotion give partially positive and significant effect on the consumer's desire to use OVO servicesnot ordered can also be diverted to make products that consumers are most ordered or interested in [5].

\subsection{The influence of convenience, easy usage, and promotion towards people's interest in using OVO applications (Non Cash) in Denpasar City}

Based on the calculations done, obtained Fhitung $=1502.002$ compared to Ftabel value $=3.1$, it turns out the Fhitung value is greater than the Ftabel value. This means that in a state of convenience (X1) and a constant promotion (X3), statistically on the level of trust $(\alpha)=5 \%$, the user's convenience (X2) affects significant/positive towards the interest (Y). This is in line with the research conducted by Wiwik Widiyanti (2020) which expressed the positive and significant influence simultaneous between benefits, easy usage, and promotion variables to the decision of the use of e-wallet OVO [6]. Although OVO has many advantages, it turns out that OVO has several shortcomings, among which the users must always have internet data while trading because OVO e-wallet application is connected to the internet, and also other complaints from users is OVO gives too many application updates. Another thing that makes users feel inconvenient is top up through certain banks that is charged with admin fees. These things can be a consideration for OVO application to continuously innovate and improve its service.

\section{Conclusion}

Based on the analysis that has been done to determine the influence of convenience, easy usage, and promotion towards people's interest, it can be concluded that: 
1. Convenience has positive and significant effect on interest.

2. Easy usage has positive and significant influence on interest.

3. Promotions have a positive and significant effect on interest.

4. Convenience, easy usage, and promotion all together give a positive and significant influence on interest. The analysis of multiple determinations resulted determination coefficient of $97.9 \%$

\section{References}

[1] Suharsimi, A.:Prosedur penelitian suatu pendekatan praktik. Jakarta: Rineka Cipta, (2006).

[2] Masyhuri, M. Z.:Metodologi penelitian pendekatan praktis dan aplikatif. Bandung: PT. Refika Aditama, (2008).

[3] Jayaningrum, V. A.: Analisis Faktor-Faktor Yang Mempengaruhi Penerimaan Dan Penggunaan Mobile Payment Pada Teknologi Pembayaran OVO, Univeristas Sanata Dharma Yogyakarta, (2019).

[4] Iliyin, A. and Widiartanto, W.: Pengaruh Persepsi Kemudahan Penggunaan Dan Persepsi Keamanan Tehadap Keputusan Pengunaan OVO PT Visionet Data Internasional (Studi Pengguna OVO Di Kota Surakarta), J. Ilmu Adm. Bisnis, vol. 10, no. 1, pp. 85-92, (2020).

[5] Syafutra, A.: Pengaruh Promosi, Iklan Dan Kemudahan Bertransaksi Terhadap Keinginan Konsumen Untuk Menggunakan Layanan Jasa OVO, Universitas Brawijaya, (2019).

[6] Widiyanti, W.: Pengaruh Kemanfaatan, Kemudahan Penggunaan Dan Promosi Terhadap Keputusan Penggunaan E-Wallet OVO Di Depok, Monet. Akunt. dan Keuang., vol. 7, no. 1, pp. 54-68, (2020). 